\title{
The Dynamics of Energy-Grain Prices with Open Interest*
}

\author{
Shawkat Hammoudeh \\ Lebow College of Business \\ Drexel University, USA \\ Soodabeh Sarafrazi \\ Lebow College of Business \\ Drexel University, USA \\ Chia-Lin Chang \\ Department of Applied Economics \\ Department of Finance \\ National Chung Hsing University \\ Taichung, Taiwan \\ Michael McAleer \\ Econometric Institute \\ Erasmus School of Economics \\ Erasmus University Rotterdam \\ and \\ Tinbergen Institute \\ The Netherlands \\ and \\ Institute of Economic Research \\ Kyoto University, Japan \\ and \\ Department of Quantitative Economics \\ Complutense University of Madrid
}

May 2011

*For financial support, the third author wishes to thank the National Science Council, Taiwan, and the fourth author acknowledges the Australian Research Council, National Science Council, Taiwan, and the Japan Society for the Promotion of Science. 


\begin{abstract}
This paper examines the short- and long-run daily relationships for a grain-energy nexus that includes the prices of corn, crude oil, ethanol, gasoline, soybeans, and sugar, and their open interest. The empirical results demonstrate the presence of these relationships in this nexus, and underscore the importance of ethanol and soybeans in all these relationships. In particular, ethanol and be considered as a catalyst in this nexus because of its significance as a loading factor, a long-run error corrector and a short-run adjuster. Ethanol leads all commodities in the price discovery process in the long run. The negative cross-price open interest effects suggest that there is a money outflow from all commodities in response to increases in open interest positions in the corn futures markets, indicating that active arbitrage activity takes place in those markets. On the other hand, an increase in the soybean open interest contributes to fund inflows in the corn futures market and the other futures markets, leading to more speculative activities in these markets. In connection with open interest, the ethanol market fails because of its thin market. Finally, it is interesting to note that the long-run equilibrium (cointegrating relationship), speeds of adjustment and open interest across markets have strengthened significantly during the 2009-2011 economic recovery period, compared with the full and 2007-2009 Great Recession periods.
\end{abstract}

Keywords: Energy-grain price nexus, open interest, futures prices, ethanol, crude oil, gasoline, corn, soybean, sugar, arbitrage, speculation.

JEL: E43, Q11, Q13. 


\section{Introduction}

The rising prices of commodities including oil, bio-fuels and grains such as corn, soybeans and sugar, have stoked fears that commodity inflation will filter through the supply chains and cause high food and overall inflation. Some economic analysts have attributed the hikes in grain prices to increases in the energy demand for bio ethanol and oil. These analysts have questioned the prevailing view that the culprits underlying the rising trend in agricultural commodity prices are meat carnivores in countries like China and India, droughts in Russia and Eastern Europe, or heavy rain in North America. ${ }^{1}$

An alternative view is that the real culprits are increases in the consumption of oil, ethanol and other bio-fuels which, through the derived demand, have led to increases in prices of these goods, as well as food. In fact, some agricultural economists consider ethanol as the catalyst that has closely linked energy and agricultural products since the start of the ethanol boom in 2006 (Tyner, 2008).

Financial analysts view the trade of commodities by financial investors who are not connected directly with agriculture (the so-called "financialization of commodities") as partially responsible for the recent price spikes (Baffes and Haniotis, 2010). ${ }^{2}$ Simple hedging contracts between buyers and sellers of foods turned into derivatives that have led to the creation of unreal "food speculation" markets that have nothing to do with agriculture.

\footnotetext{
${ }^{1}$ Paul Krugman, for example, has attributed the recent drastic increase in grain prices between 2008-2009 and 20102011 to bad harvests (see "Soaring Food Price" at: http://krugman.blogs.nytimes.com/2011/02/05/soaring-foodprices/.

2 UN and food experts have attributed food inflation to "natural and human factors" that had taken land out of production of food to grow bio-fuel for vehicles, oil and fertilizer prices that had risen steeply, Chinese shifting to meat from a vegetarian diet, and climate-change linked droughts that have been affecting major crop-growing areas. However, a new theory has emerged that has accused banks, hedge funds and financiers who took advantage of deregulation of global commodity markets of causing food prices to "yo-yo and inflate" (see http://www.guardian.co.uk/global-development/2011/jan/23/food-speculation-banks-hunger-poverty).
} 
These newly-born markets were enabled by the deregulation of commodity markets in the mid 1990s, which turned regional markets into global markets. Consequently, billions in funds were transferred from pension funds and mutual equity funds to global safe haven commodities, particularly foods.

This paper will focus on the view that deals with the "financialization" of commodities. It will be interesting and useful to examine how the prices of oil, ethanol, corn, soybeans and sugar behave and how they relate to each other. In particular, it will also be useful to determine whether oil and ethanol prices are related, and whether they lead the prices of corn, soybeans and sugar. In this case, we will examine the transmission of prices and returns within the energyfood nexus, and whether agricultural economists are correct in branding ethanol as the catalyst in this nexus.

It will be of special interest to determine whether the oil price affects food prices directly through its impact on ethanol, which is extracted from corn in the United States, thereby indirectly affecting fertilizers' prices and transportation costs. Additionally, there is complementarity and substitutability between corn and soybeans and between corn and sugar, all of which share same planted acreage (Takgoz et al. (2008)).

Such information will be useful for farmers, investors, hedgers and speculators who are involved in these markets. The relationships between these basic commodities are also greatly sensitive for politicians in many countries, particularly where the share of food cost in household budgets is high. Food inflation is causing political unrest in countries that are neighboring major oil-exporting countries. Sticker inflation at supermarkets can trigger mass consumer inflation psychology. 
The empirical results could also assist decision-makers in making better macroeconomic policies and sounder regulations of energy and food markets, particularly in developing markets such as Nigeria, where the food basket could reach more than $70 \%$ of the household budget.

This remainder of the paper is organized as follows. Section 2 presents a review of the literature, Section 3 provides a description of the data, Section 4 discusses the methodology, Section 5 analyses the empirical results, and Section 6 gives some concluding remarks.

\section{Review of the Literature}

The commodities literature has investigated cointegrating relationships primarily between spot and futures prices for different combinations of agricultural commodities, but with no strong emphasis on the relationship among fuels, bio-fuels and agricultural commodities. In this paper, we analyse a broad combination of commodity prices that includes fuel and agricultural commodity prices in the energy-grain price nexus, and investigate the resulting supply chain impacts. We also use updated data that takes into account the recent acceleration in fuel and agricultural products. The paper examines the prices of oil, gasoline and ethanol, as well as the prices of corn, soybeans and sugar.

Garbade and Silber (1982) investigate the price movements and price discovery function in the spot and futures markets for seven storable, agricultural and non-agricultural commodities, including corn, wheat, oats, orange juice, copper, gold and silver, but with no analysis of fuels. Their findings indicate that futures prices generally dominate spot price changes for most of these commodities. The empirical evidence suggests that the futures markets dominate the spot markets for corn, wheat and orange juice for 70 percent of new information arriving in the 
markets. The authors find a similar case for the gold market, but the leading pricing power in the silver, oats and copper markets is divided between the spot and futures markets.

Yang et al. (2001) address the price discovery function for non-fuel, storable (corn. oats, soybeans, wheat, cotton and Pork bellies) and non-storable (hogs, live cattle, feeder cattle) commodities. They find that although, in general, storability does not affect the futures price discovery function, futures contracts can be used as a price discovery tool in all of these markets. They also find that large differences in trading volumes of these commodities have little effect on the predictive power of the corresponding futures prices.

Wang and Ke (2002) assess the long- and short-run efficiency of futures and spot prices of Chinese wheat and soybean, accounting for different maturities of the futures contracts. Their findings imply that there exists a long-run relationship between futures and spot prices for soybean in China, but the short-run lead-lag relationship is weak. However, wheat futures contracts are found to be inefficient, possibly due to government interventions in the wheat market.

Zapato et al. $(2003,2005)$ examine cointegration between New York futures price and the Dominican Republic spot price for sugar. Their empirical evidence suggests that the World Futures Sugar (WFS) price has predictive power for the spot price for a small sugar-producing country. It is found that futures prices, in general, appear to play a dominant role in the price discovery mechanism. However, there appears to be neither long-run relationships nor short-run leads in these tightly-traded markets.

Mattos and Garcia (2004) investigate the relationships between spot and futures prices in six Brazilian non-fuel agricultural markets (Arabic coffee, corn, cotton, live cattle, soybeans and sugar). All these Brazilian markets are considered thinly traded in terms of trading volume, 
compared with those in the United States. This paper has two surprising results relative to those of the US markets. First, the thinly-traded sugar futures contracts show evidence of some degree of long-run relationships (cointegration) with spot prices, with the futures price playing the dominant role. Second, the heavily-traded corn contracts show almost no interrelations between the futures and cash prices. However, both the Brazilian sugar and corn markets have their own peculiarities that may account for these surprising results.

Although the overall empirical results have been mixed, as indicated above, Dahlgran (2009) investigates the relationship between ethanol futures contracts, which are thinly traded, and gasoline futures contracts, which are tightly traded. The evidence suggests that the former has hypothetically superior price risk hedging capabilities than the former because ethanol swaps add depth to its futures market.

In a related area, Tyner (2010) explores the integration of energy and agricultural markets. This paper addresses the evolving relationships between the prices of crude oil, gasoline, ethanol and corn, and finds that there is little correlation between these prices before 2005. However, a strong link emerged among oil, gasoline and corn in the ethanol boom period of 2006-2008, particularly in the relationship between the prices of ethanol and corn. The relationship between the prices of ethanol and corn strengthened in late-2008 and 2009 as ethanol production came under severe pressure, leading to a causal relationship from corn to ethanol prices.

Gohin and Treguer (2010) develop a partial equilibrium model focusing on ethanol production with downside risk-averse corn farmers. The objective is to assess the impact of ethanol production on agricultural volatility, particularly corn. The results show a substantial ethanol impact on the distribution of corn prices. Risk-averse corn farmers can still benefit due to the higher mean price effect, despite increases in the corn price variance. 
Using a multi-commodity, multi-county partial equilibrium model to examine the impact of expanded US ethanol production on planted acreage crop prices, livestock production and retail food prices, Tokgoz et al. (2008) find that the expanded ethanol production would increase both the long-run prices of crops and livestock, with the increase in the latter greater than the former. The authors also indicate that an increase in the price of oil would lead to an expansion in the US ethanol sector.

Balcombe and Rapsomanikis (2008) develop a range of generalized bivariate error-correction models to explore the nonlinear long-run price relationships in the sugar-ethanol-oil nexus. The models were estimated using the Bayesian Monte Carlo Markov Chain method. The estimates suggest that the long-run drivers of Brazilian sugar prices are oil prices. The price adjustments are non-linear and causal from the oil price to sugar and ethanol prices, but linear between ethanol and sugar prices.

Based on the above review, most of the commodity literature has concentrated on agricultural commodities, particularly on spot and futures prices. However, some have examined this function for the ethanol market in different markets and locations. Nevertheless, most of these studies have not been sufficiently comprehensive to include the prices of energy and agricultural commodities. A large portion of this literature has focused on the price discovery function between futures and spot prices in bivariate models. This paper will examine the relationships among the futures prices of crude oil, gasoline, ethanol, corn, soybeans and sugar in a multivariate setting, using recent data. The paper will also account for the confounding impacts of open interest, which may provide depth to the markets.

\section{Data Description}


This paper uses daily time series data on the closing futures prices of six highly-traded and closed-linked energy and agricultural commodities, specifically crude oil, gasoline, bio-fuel ethanol, corn, soybeans and sugar. The sample covers the period June 2, 2006 to January 13, 2011, and the length of this period was dictated by the availability of data, particularly on bioethanol. As we account for the presence of lagged open interest in this analysis of the energygrain price nexus, we will examine the futures prices for these six commodities.

The ethanol futures price is sourced from Thompson Reuters and is expressed in US dollars per gallon. The data on the ethanol futures price are for ethanol traded on eCBOT. Its class is CZE and is expressed in US dollars per bushel wheat (BW). Data on corn futures are sourced from Datastream for the US market. The corn futures class is CC, is traded at CBOT, and is expressed in dollars per bushel. The futures soybean trades at CBOT and its price is expressed in dollars per bushel, and the class is CS. The futures sugar is sugar \# 11 (class NSB), is expressed in dollars per pound, and is traded at the New York Board of Trade (NYBOT). The crude oil is the West Texas Intermediate (WTI) three-month futures traded at the New York Mercantile exchange (NYMEX), and RBOB gasoline is the New York Harbor Reformulated RBOB Regular Gasoline Future Contract 3.

The descriptive statistics for the futures returns of the six energy and agricultural commodities are given in Table 1. Grain prices yield, on average, higher returns than energy prices over the full period. The highest mean return is for soybean, followed by corn. The high return for soybeans reflects increases in demand by new meat carnivores in countries such as China and India, and droughts in Russia and Eastern Europe. The relatively high return for corn may additionally reflect higher oil and ethanol prices, and a targeted government policy to promote corn-based ethanol production to be used increasingly as an additive to conventional 
gasoline. Traders and speculators also "financialize" these commodities, and contribute to subsequent price increases. The average return for crude oil and RBOB gasoline come before that of ethanol, which yielded a negative return in the sample period. Ethanol price came under heavy pressure in late-2008 and 2009 as two billion gallons of its 12 billion gallons of capacity were shut down. During this period, ethanol was priced more heavily on corn (Tyner, 2010).

\section{[Table 1 goes here]}

Commensurate with the highest average return, soybean has the highest volatility, as defined by the standard deviation. This is somewhat surprising because soybean futures contracts are not the most thinly traded among these six commodities. However, the increase in demand from the new carnivores may also have increased soybean volatility. Ethanol has a similar volatility to those of crude oil and RBOB gasoline, which is nevertheless significantly lower than the volatility of soybean and corn. Ethanol has its peculiarities as, on the one hand, it is the most thinly traded among the six commodities, which should make it highly volatile. On the other hand, ethanol receives tax credit, and has a government production mandate and blend-wall constraints which should account for a relatively lower volatility.

All of these energy and grain returns have asymmetric distributions, as shown in the skewness and kurtosis statistics. Interestingly, all of the returns are skewed to the left, indicating that these commodities have longer left tails (extreme losses) than right tails (extreme gains). This stylized fact should be of interest to the participants in these commodity markets. The similarity in negative skewness among these energy and agricultural commodities may be related to their "financialization". 
All of the distributions have kurtosis that is significantly higher than 3 , implying higher probabilities of extreme market movements in either direction (gains or losses) occurring in these markets, with greater frequency in practice than would be predicted by the normal distribution. The highest kurtosis is for ethanol, followed by sugar, while the lowest is for corn, despite the complementarities between corn and ethanol. The Jarque-Bera Lagrange multiplier statistics confirm the non-normal distributions of all the return series.

The contemporaneous correlation matrix for the six returns is provided in Table 2. As expected, the highest correlation is between RBOB gasoline and crude oil, which is used as a feedstock in producing gasoline and leads to more than $50 \%$ of the cost in the former. The second highest correlation is between corn and soybean, n which are used as feedstock to produce meat and share the same cropland. The lowest correlation is between ethanol and sugar, which is due to the fact that US ethanol is derived from corn and not from sugar. In fact, sugar has the lowest correlations with all the other returns.

\section{[Table 2 goes here]}

We use the ADF and Phillips-Perron (PP) tests to check the stationarity in all prices, as displayed

in Table 3. The ADF and PP tests show that all commodities have unit roots, or are I(1). Therefore, VAR and VEC models will be estimated in terms of the log-differences in prices to avoid spurious regressions and inferences.

[Table 3 goes here] 


\section{Methodology and Empirical Results}

Let $X_{t}$ denote a $p$-dimensional column $I(1)$ variables, which follows the following $\operatorname{VAR}(k)$ process:

$$
X_{t}=A_{1} X_{t-1}+A_{1} X_{t-2} \ldots+A_{1} X_{t-k}+\mu+\varepsilon_{t}
$$

where $\mu$ is a deterministic term of $I(0)$ elements, $k$ is the order of lag length, and $\varepsilon_{t}$ is a Gaussian error term. The $\operatorname{VAR}(k)$ process can be written in the following VECM representation:

$$
\Delta X_{t}=\Pi X_{t-1}+\sum_{i=1}^{k-1} \Gamma_{i} \Delta X_{t-i}+\mu+\varepsilon_{t}
$$

where $\Pi$ and $\Gamma_{i}$ are pxp matrices of coefficients repressing the long-run impacts and the shortrun adjustments, respectively. The matrix $\Gamma_{i}$ represents the interim multipliers.

The hypothesis of cointegration states that the long-run impact matrix, $\Pi$, can be rewritten as:

$$
\Pi=\alpha \beta^{\prime}
$$

where $\alpha$ and $\beta$ are pxr matrices. The row of matrix $\alpha$ forms the cointegrating vectors, while matrix $\beta$ contains the loading factors, which are the weights of the cointegrating vectors in the various equations. These matrices are of full rank $r$, such that $0 \leq r \leq p-1$, given $X_{t}$, is an $I(1)$ process. If $r=0$, then no cointegration relationship exists among the elements of $X_{t}$. If the rank $0 \leq r \leq p-1$, then there are $r$ cointegration vectors. It suggests that $r$ stationary linear combinations of the elements of $X_{t}$ exist, with $p-r$ common stochastic trends. 
We use the Johansen (1995) method to test the rank of the impact matrix, П. We can also perform the Granger causality test based on equation (2). If all $\Gamma_{i}(m, n)$ are jointly not equal to zero, then the $n$th variable in vector $X$ Granger causes the $m$ th variable. Otherwise, the $n$th variable does not cause the $m$ th variable. The joint significance can be tested by various methods such as the F, Wald or LR tests, as will be seen below.

In this paper, the VAR dimension $p$ is six, representing the corn, crude oil, ethanol, RBOB gasoline, soybeans and sugar futures prices. The empirical results will be useful in determining whether these commodities can lead or lag in processing new information, and whether they can be included in a diversified portfolio that may help diversify risk in the long run. They can also reveal the impacts of market liquidity and depth as represented by open interest. ${ }^{3}$ We will examine the VEC models for the VAR if the tests show cointegration in order to examine the short- and long-run deviations of the prices from their equilibrium levels.

\subsection{Cointegration of agricultural and energy commodities}

There are many possible tests for detecting cointegration, the most general being the multivariate tests based on the autoregressive representation, as discussed in Johansen (1988) and Johansen and Juselius (1990). The Johansen maximum likelihood method provides two different likelihood ratio tests, the trace and maximum eigenvalue tests, which determine the number of cointegrating vectors. We will also use the Akaike Information Criterion (AIC) and Schwartz Bayesian Criterion (SBC) to determine the VAR and cointegration specifications, and their respective lag lengths.

\footnotetext{
${ }^{3}$ Trading volumes are $\mathrm{I}(0)$, and therefore could not be included.
} 
Johansen's cointegration test for the system of six grain-energy prices suggest that there is only one cointegrating vector among those commodities, according to both the trace and maxeigenvalue tests, under the specification of intercept and no trend in the cointegrating equation and VAR (Table 4). It is not surprising to have one cointegrating relationship between these six different fuel and grain commodities. There are five common stochastic shocks that push them away from the long-run equilibrium. This result implies that there is only one long-run equilibrium relationship among these commodities.

\section{[Table 4 goes here]}

In this cointegration relationship, which co-moves the six prices in a long-run relationship along the equilibrium, the loading factors of the corn price are all the other prices in the system, with the exception of the sugar price, which does not co-move (Table 5). This relationship suggests that the prices of soybeans, followed by the prices of RBOB gasoline and ethanol in this importance sequence, have a significant positive relationship with the price of corn, while the crude oil price has a significant negative relationship. Corn and soybeans are major global food items and share cropland, while gasoline impacts the corn price through their substituting relationship with ethanol. Moreover, ethanol is corn-based in the United States, which explains the cointegrating relationship. On the other hand, an increase in the crude oil price stimulates production of alternative sources of energy, such as ethanol, and leads to a reduction in their prices within the long-run equilibrium relationship.

\section{[Table 5 goes here]}


This long-run equilibrium result is closer to the countervailing view which suggests that the lead comes from oil and gasoline to agricultural prices. Crude oil, RBOB gasoline, soybeans and corn contracts are highly liquid and tightly traded, compared with ethanol, which is thinly traded. However, it is surprising that sugar is not driving the long-run relationships. Part of the sugar supply in the United States is imported and subjected to import quotas. Moreover, the anecdotal evidence shows that sugar has the lowest correlations with the other prices in the fuelgrain nexus.

The presence of cointegration paves the way for the return adjustments to reduce the deviations from the long-run equilibrium, as captured by the vector-error correction (VEC) models, which will be discussed below.

\subsection{Vector Error Correction Model}

The long- and short-run results for the VEC model are reported in Table 6. The ECT terms for corn, ethanol, soybeans and RBOB gasoline returns have the desired signs for errorcorrecting in the adjustment to the long-run equilibrium, but only ethanol and soybean have significant ECTs. In addition to its significance as a loading factor in the long-run equilibrium relationship, ethanol adjusts in the long run through its ECT. The ECTs for crude oil and sugar returns do not have the correct signs, and thus are not self-correcting in the long run, suggesting that the prices of these two commodities are exogenous in the long run. It is also surprising that gasoline and WTI do not behave similarly in the cointegrating relationship.

\section{[Table 6 goes here]}


Based on the significance and sizes of the ECTs, or speeds of adjustment, for the six returns, ethanol has the highest speed, implying that ethanol leads in the price discovery in the long run, and hence is the catalyst in the energy-grain nexus.

All the returns of these commodities adjust to the equilibrium in the short run, with the exception of corn. However, the short-run adjustments among all these commodities are limited. The most interesting lead/lag return relationships are those from ethanol to both gasoline and WTI. These short-run relationships are negative, suggesting that an increase in ethanol returns leads to a decrease in the returns of gasoline and WTI, but with no reverse feedback. There is also a short-run transmission from soybean to WTI, but not to gasoline. This may reflect the impact of macroeconomic factors on these commodity prices. Thus, only ethanol and soybean, of the four agricultural commodities, affect WTI and gasoline returns.

There are also transmissions of returns from soybeans to sugar, and from crude oil to soybeans and RBOB gasoline in the short run. However, increases in oil returns do not lead to increases in the returns of gasoline, which uses crude oil as a feedstock, and soybean, which uses crude oil in fertilizers.

While the corn return shows no error corrections in the long run, and no adjustments in the short run, the open interest effects demonstrate that increases in open interest in the corn futures position lead to money outflows from the ethanol, soybean, sugar, crude oil and RBOB gasoline markets. The greatest reaction comes from the WTI and ethanol markets. The negative cross open interest effect implies that there is active arbitrage activity in all the markets. On the other hand, an increase in the soybean open interest contributes to fund inflow in the corn futures 
market, as well as to all the other futures markets. It may be concluded that an increase in soybean futures positions leads to increases in speculative activity in all the commodities. There are no significant effects from changes in the ethanol open interest. This is not surprising because this commodity is thinly traded and lacks strong market depth.

The significant results are confirmed by the weak exogeneity tests (Urbain, 1992), as displayed in Table 6. The results of the long-run Granger non-causality exogeneity test indicate that there is a long-run Granger causality for ethanol because this commodity price variable is the leader in the price discovery process, and has significant effects as a load factor. The weak exogeneity test suggests that soybean plays a significant role in the long-run equilibrium, given that its beta parameter is not equal to zero in the VECM system.

The results for the multivariable block exogeneity Wald test derived from the VEC model, which examines the additional causal relationship between each dependent variable and the lagged endogenous variables in the VEC equation, are significant for ethanol and soybean returns. The null hypothesis is that the lagged endogenous variables for these variables do not Granger-cause the dependent variable, but the null is rejected. This result is expected, given the fact that the lagged endogenous variables are significant, and shows that this model is superior to the naïve model.

\subsection{Variance decompositions and Impulse Response Functions}

The forecast-error variance decompositions (VDC) capture how much of the variance of a particular variable can be explained by shocks in another variable in the same system. Unexpected shocks to an individual variable can affect both the variable itself and the other 
variables in the model. On the other hand, the generalized impulse responses (GIRF) show the dynamic responses of a variable to shocks in other variables in the VAR.

The results of the generalized forecast error variance decompositions are reported in Table 7. The results indicate that there is a strong relationship among the variables, but with to a smaller extent than the sugar return. Most of the variation in the forecast error variances is captured by their own shocks, with the exception of more than $50 \%$ of the crude oil variance, which is explained by gasoline. Most of the decomposition of the variances are among corn, ethanol, soybeans, gasoline and crude oil. As explained previously, corn behaves as an exogenous variable, as can be seen by its impact in the decomposition of the returns of all the energy and grain commodities. This influential cross-relationship for corn is evident in the case of ethanol and soybeans.

\section{[Table 7 goes here]}

The GIRF results indicate that all the impulse response trajectories are similar, but the differences are in the relativity of the adjustments (Figure 1). We can summarize the results by the following points. The initial impact of the shocks in all returns to their own shocks is positive

and significant. Then the responses decline slowly and gradually, but stay positive even after 50 days have passed. Analogous to the case of variance decomposition, the results also demonstrate the significance of the responses of ethanol, soybeans, gasoline and crude oil to a shock from corn, where the initial positive responses continue to rise slightly over the 50-day horizon.

\section{[Figure 1 goes here]}


The responses of the other returns to a shock from ethanol are positive and persistent for sugar, crude oil and gasoline. The response is negative and insignificant for corn, and dies out for soybeans. Soybean is less influential in this energy-grain price nexus than ethanol and corn. Its impact is more evident on crude oil and gasoline, but is very small on sugar and insignificant for corn. Sugar is the least influential of all the returns, but still has a modest positive impact on crude oil and gasoline.

Crude oil and gasoline have their strong return responses and impacts on themselves, and on each other. The response of gasoline to crude oil is strong initially, but declines persistently over the 50-day horizon. On the other hand, the response of crude oil to gasoline is initially modest, but rises slowly over the horizon.

\subsection{Cointegration in the Recovery Subperiod}

We measure cointegration among the six energy and grain prices over the full period and for

three subperiods, as given below. The first subperiod starts at the beginning of the 2007-2009 Great Recession period on 12/03/2007 and ends at the end of sample, dated 1/13/2011 (see Table 4). The second is the economic recovery subperiod, which starts from the post-Recession Recovery dated 7/01/2009 and continues to $1 / 13 / 2011$, at the end of the sample. The third subperiod is the 2007-2009 Great Recession subperiod, which spans the period from 12/03/20076/01/2009.

The full period and the three subperiods are in agreement that there is one long-run (cointegrating) equilibrium relationship among the six prices, according to both the trace and maximum eigenvalues tests under almost all the specifications of trend and VARs (see Table 8). 
However, the long-run equilibrium (cointegrating) relationship has the most significant drivers during the 2009 economic recovery period, compared with the full and the other two subperiods. Moreover, the relative strength and significance of the drivers in this long-run equilibrium relationship differ. They have the strongest impact during the recovery subperiod and the weakest during the first subperiod. $^{4}$

\section{[Table 8 goes here]}

Ethanol has the strongest driving force during the first period, while soybean is the strongest during the recovery period, probably corresponding to the strengthening of the economic recovery in the carnivore countries like China and India, and countries in Eastern Europe. These empirical results demonstrate that the long-run relationship for these six prices is sensitive to the economic stages of the business cycle.

The VEC results of the 2009 Recovery subperiod are available in Table 9. These results are different from those of the full sample that are displayed in Table 6. The speeds of adjustment are higher for all commodities in the Recovery subperiod than for the full period. More commodities have significant open interest in the Recovery subperiod than in the full period. Interestingly, the thinly-traded ethanol has own and cross open interest effects for the subperiod that are significant, being negative for ethanol and soybeans, indicating arbitrage, and positive for ethanol and sugar, suggesting speculative behaviour. Tyner (2010) contends that US ethanol experienced large increases in production, which led to surpluses and contributed to a shutdown in two billion gallons of US ethanol capacity in late 2008 and 2009. The cross open interest for sugar is also significant and negative, signalling arbitrage activity with respect to corn, ethanol and soybeans.

\footnotetext{
${ }^{4}$ The VEC results for the first subperiod are available upon request.
} 


\section{[Table 9 goes here]}

\section{Conclusions}

This paper examined the long- and short-run relationships between crude oil, RBOB gasoline, ethanol, corn, soybean and sugar in the energy-grain nexus, over the period 06/02/1996-01/13/2011 and the subperiod 07/1/2009-01/13/2011 that characterizes the economic recovery, following the 2007/2009 Great Recession. The conventional view suggests that this relationship is from crude oil to gasoline to ethanol. The latter is postulated to be the catalyst that extends the relationship to corn, soybeans and sugar. The empirical results showed that crude oil and gasoline drive ethanol, soybean and each other, but not corn and sugar, in the long run, lending some support to the conventional view.

In the short run, the variance decomposition and IRF analyses reveal multiple responses and impacts among the returns of the variables. There are stronger impacts from ethanol, corns and soybeans than the reverse. The impact between crude oil and gasoline is from the latter to the former. Moreover, the impact of crude oil and gasoline on ethanol is limited. Thus, the conventional view does not hold strongly in the short run.

Policy makers and energy market participants should pay great attention to the impact of corn in this energy-grain price nexus. Moreover, the impact of ethanol on crude oil and gasoline return is more significant than the reverse. In order to disentangle corn from the energy-grain price nexus, the markets should find an alternative source to provide unconventional gasoline than corn and corn-based ethanol. It may well be entirely appropriate and timely for green energy policy to undertake such disentangling. 
The negative cross-price open interest effect suggests that there is money outflow from all commodities in response to increases in open interest positions in the corn futures markets. There are also indications that active arbitrage activity occurs in these markets. On the other hand, an increase in soybean open interest contributes to fund inflows in the corn futures market and the other futures market, leading to greater speculative activities in these markets.

Finally, in the Recovery subperiod, the grain-energy commodity markets demonstrate greater speeds of adjustment and higher liquidity, as manifested in more significant open interest effects which, in turn, points to more arbitrage activity than speculative behaviour. 


\section{References}

Baffes, J. and Haniotis, T. (2010). "Placing the 2006/08 commodity price boom into perspective." Policy Research Working Paper 5371, World Bank. http://wwwwds.worldbank.org/external/default/WDSContentServer/IW3P/IB/2010/07/21/000158349_2010 0721110120/Rendered/PDF/WPS5371.pdf.

Balcombe, K. and Rapsomanikis, G. (2008). "Bayesian estimation and selection of nonlinear vector error correction models: The case of the sugar-ethanol-oil nexus in Brazil". American Journal of Agricultural Economics 90, 658-668.

Dahlgran, R.A. (2009). "Inventory and transformation hedging effectiveness in corn crushing." Journal of Agricultural and Resource Economics 34, 154-171.

Dahlgran, R.A. (2010). "Ethanol futures: Thin but effective? Why?" Proceedings of the NCCC134 Conference on Applied Commodity Price Analysis, Forecasting and Market Risk Management. St. Louis, Missouri. http://www.farmdoc.illinois.edu/nccc134.

Franken, J.R.V. and Parcell, J.L. (2003) "Cash ethanol cross-hedging opportunities." Journal of Agricultural and Applied Economics 35, 509-516.

Garbade, K. and Silber, W.L. (1982). "Price movements and price discovery in futures and cash markets." Review of Economics and Statistics 64, 289-297.

Gohin A. and Treguer D. (2010). "On the (de)stabilization effects of biofuels: Relative contributions of policy instruments and market forces." Journal of Agricultural and Resource Economics 35, 72-86.

Johansen, S. (1988). "Statistical analysis of cointegrating vectors." Journal of Economic Dynamics and Control 12, 231-254.

Johansen, S. and Juselius, K. (1990). "Maximum likelihood estimation and inferences on cointegration-with application to demand for money." Oxford Bulletin of Economics and Statistics 52, 169-210.

Lin, W. and Riley, P.A. (1998). "Rethinking the soybeans-to-corn price ratio. Is it still a good indicator for planting decisions?" Economic Research Service, US Department of Agriculture, Washington, D,C., April, 1-33. http://www.ers.usda.gov/publications/corn/crnprato.pdf

Mattos, F. and Garica, P. (2004). "Price discovery in thinly traded markets: Cash and futures relationships in Brazilian agricultural futures markets." Proceedings of the NCCC-134 
Conference on Applied Commodity Price Analysis, Forecasting and Market Risk Management. St. Louis, Missouri. http://ageconsearch.umn.edu/bitstream/19019/1/cp04ma02.pdf

Tokgoz, S., Elobeid, A. Fabiose, J., Hayes, D.J., Babcock, B.A., Yu, T.H. and Dong, F.X. (2008). "Bottlenecks, drought, and oil price spikes: Impact on U.S ethanol and agricultural sectors." Review of Agricultural Economics 30, 604-622

Tyner, W.E. (2010). "The integration of energy and agricultural markets." Agricultural Economics 41, 193-201.

Tyner, W.E. (2008). "The US ethanol and biofuels boom: Its origin, current status and future prospect.” BioScience 58, 646-653.

Wang, H.H. and Ke, B. (2002). "Efficiency test of agricultural commodity futures markets in China." Washington State University. http://www.bm.ust.hk/ ced/Holly\%20H\%20WANG.pdf

Yang, J., Bessler, D.A. and Leathan, D. (2001). "Asset storability and price discovery in commodity futures market: A new look". Journal of Futures Markets 21, 279-300.

Zapato, H.O., Fortenberry, T. R. and Armstrong, D. (2003). "Price discovery in the futures and cash market for sugar." Paper presented at the Southern Agricultural Economics Association Annual Meeting, Mobile, Alabama, February, pp. 1-5.

Zapato, H.O., Fortenberry, T.R. and Armstrong, D. (2005). "Price discovery in the world sugar futures and cash markets: Implications for the Dominican Republic." Staff Paper \# 469, University of Wisconsin, Madison, Wisconsin.

http://www.aae.wisc.edu/pubs/sps/pdf/stpap469.pdf 


\section{Figure 1: Impulse Response Analysis}
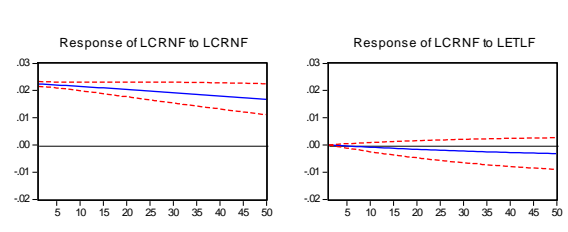

Response of LETLF to LCRNF
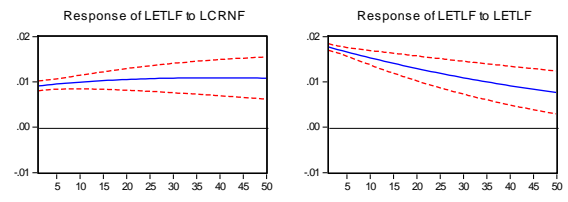

Response of LSOYF to LCRNF
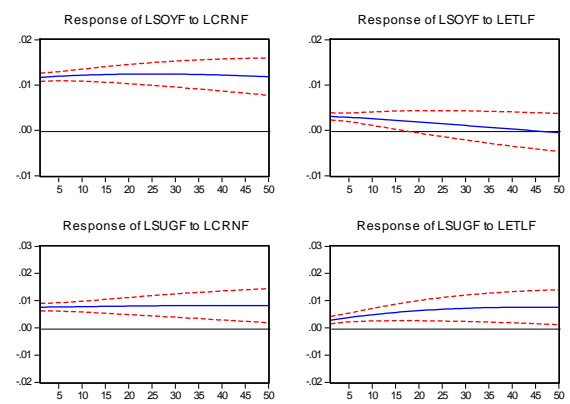

Response of LWTIF3 to LCRNF
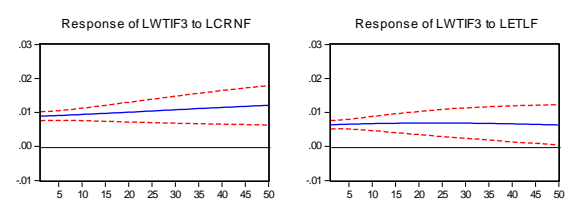

Response of LRBOBF3 to LCRNF

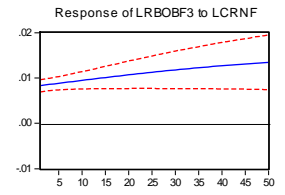

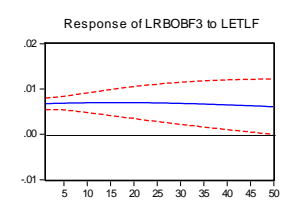

Response to Cholesky One S.D. Innovations \pm 2 S.E.
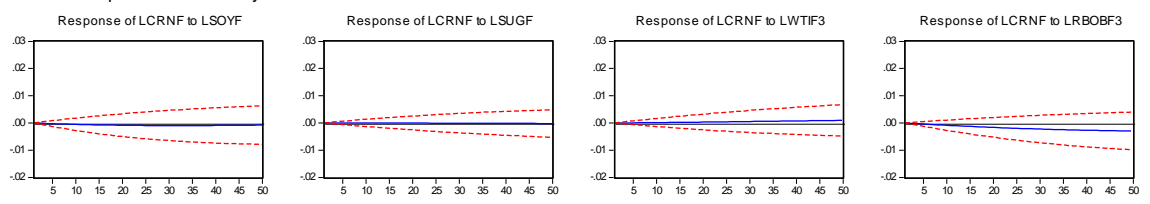

Response of LETLF to LSOYF

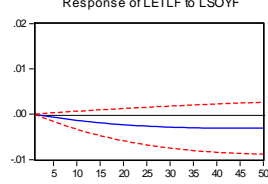

Response of LeTLF to LSUGF

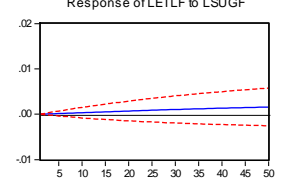

Response of LETLF to LWTIE3
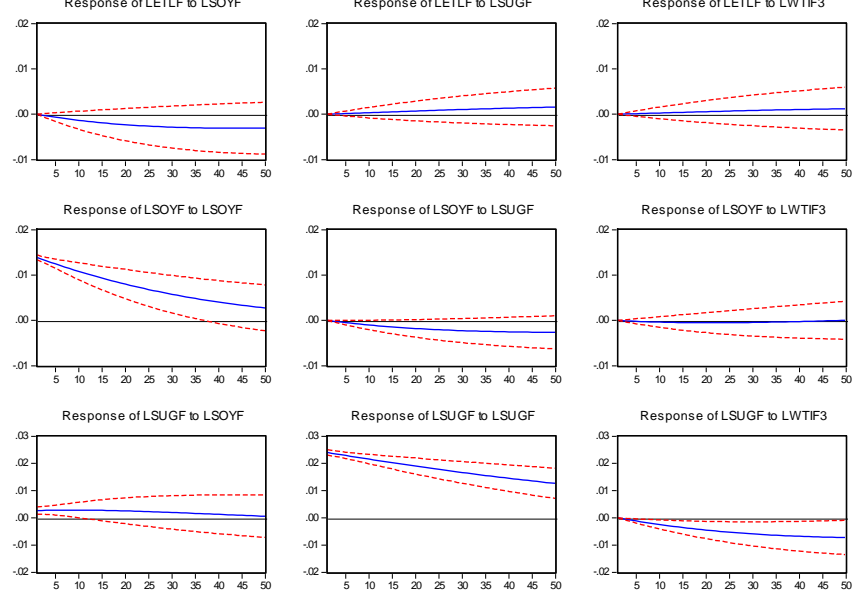

Response of LWTIF 3 to LSOYF

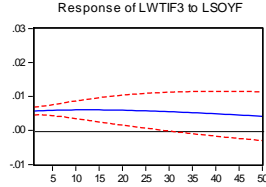

Response of LRBOBF3 to LSOYF

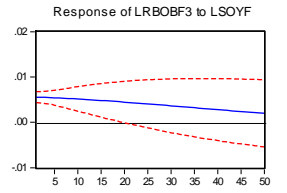

Response of LSUGF to LSUGF

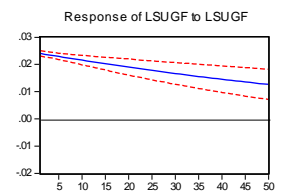

Response of LWTIF3 to LSUGF

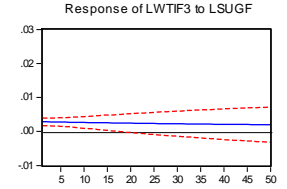

Response of LRBOBF3 to LSUGF

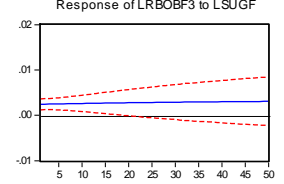

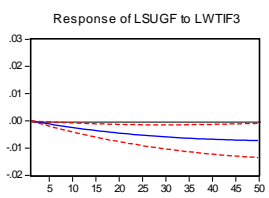
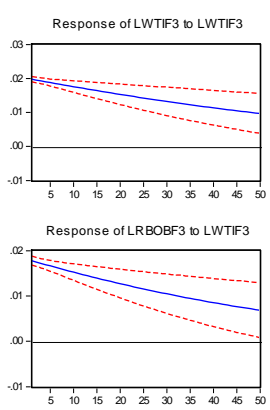

Response of LETLF to LRBOBF3

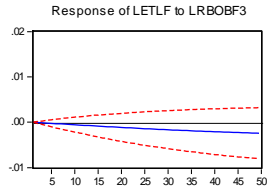

Response of LSOYF to LRBOBF3

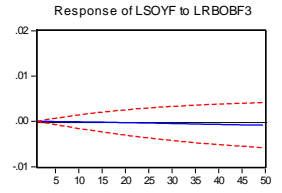

Response of LSUGF to LRBOBF3
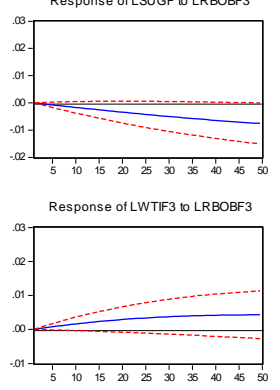

Response of LRBOBF3 to LRBOBF

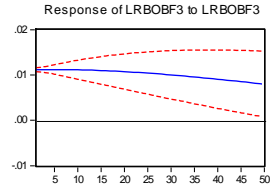

Response of LWTIF3 to LRBOBF3 
Table 1: Descriptive Statistics for Energy and Agricultural Returns (full period)

\begin{tabular}{lcccccc}
\hline & Corn & Ethanol & Soybean & Sugar & \multicolumn{1}{c}{ RBOB } & \multicolumn{1}{c}{ WTI } \\
\hline Mean & 0.00324 & -0.00106 & 0.00694 & 0.00014 & 0.00028 & 0.00041 \\
Std. Dev. & 0.09503 & 0.04440 & 0.19894 & 0.00463 & 0.04731 & 0.04236 \\
Skewness & -0.08284 & -1.81912 & -0.63757 & -1.03066 & -0.24971 & -0.17274 \\
Kurtosis & 4.51306 & 18.6107 & 7.36074 & 11.8342 & 5.60592 & 6.07666 \\
Jarque-Bera & 116.418 & 12910.8 & 1037.26 & 4135.22 & 353.772 & 481.655 \\
Probability & 0.00000 & 0.00000 & 0.00000 & 0.00000 & 0.00000 & 0.00000 \\
Observations & 1206 & 1206 & 1206 & 1206 & 1206 & 1206 \\
\hline
\end{tabular}

Notes: Returns are the first logarithmic differences of futures prices. The full sample period is June 2, 2006 to January 13, 2011. 
Table 2: Contemporaneous Correlation Matrix (full period)

\begin{tabular}{|c|c|c|c|c|c|c|}
\hline Correlations & Corn & Ethanol & Soy & Sugar & $\mathrm{RBOB}$ & WTI \\
\hline Corn & 1.000000 & & & & & \\
\hline Ethanol & $\begin{array}{c}0.437659 \\
(16.88969)\end{array}$ & $\begin{array}{c}1.000000 \\
-----\end{array}$ & & & & \\
\hline Soy & $\begin{array}{c}0.633986 \\
(28.44593)\end{array}$ & $\begin{array}{c}0.401912 \\
(15.23005)\end{array}$ & $\begin{array}{c}1.000000 \\
-----\end{array}$ & & & \\
\hline Sugar & $\begin{array}{c}0.294719 \\
(10.70169)\end{array}$ & $\begin{array}{c}0.186994 \\
(6.604951)\end{array}$ & $\begin{array}{c}0.261062 \\
(9.383945)\end{array}$ & $\begin{array}{c}1.000000 \\
-----\end{array}$ & & \\
\hline RBOB & $\begin{array}{c}0.357801 \\
(13.29542)\end{array}$ & $\begin{array}{c}0.377940 \\
(14.16463)\end{array}$ & $\begin{array}{c}0.438507 \\
(16.93016)\end{array}$ & $\begin{array}{c}0.202506 \\
(7.175352)\end{array}$ & $\begin{array}{c}1.000000 \\
-----\end{array}$ & \\
\hline WTI & $\begin{array}{c}0.409492 \\
(15.57454)\end{array}$ & $\begin{array}{c}0.396613 \\
(14.99147)\end{array}$ & $\begin{array}{c}0.478662 \\
(18.91682)\end{array}$ & $\begin{array}{c}0.242383 \\
(8.668872)\end{array}$ & $\begin{array}{c}0.897117 \\
(70.46031)\end{array}$ & $\begin{array}{c}1.000000 \\
----\end{array}$ \\
\hline
\end{tabular}

Notes: The correlations are between returns of prices for all the commodities. The t-statistics are in parentheses. 
Table 3: Unit Root Tests (full period)

\begin{tabular}{|c|c|c|c|c|c|c|}
\hline \multirow[t]{2}{*}{ Variables } & \multicolumn{3}{|l|}{ Level } & \multicolumn{3}{|l|}{ First difference } \\
\hline & $\begin{array}{l}\text { ADF } \\
\text { statistics }\end{array}$ & $\begin{array}{l}\mathrm{PP} \\
\text { statistics }\end{array}$ & Lag & ADF statistics & $\begin{array}{l}\text { PP } \\
\text { statistics }\end{array}$ & Lag \\
\hline Corn & -2.407 & -0.155 & 4 & $-33.832^{* * *}$ & $-33.831^{* * *}$ & 2 \\
\hline Ethanol & -1.671 & -1.606 & 9 & $-33.919^{* * *}$ & $-34.194^{* * *}$ & 9 \\
\hline Soybean & -1.720 & -1.609 & 12 & $-33.811^{* * *}$ & $-33.809^{* * *}$ & 12 \\
\hline Sugar & -2.522 & -3.260 & 4 & $-34.954^{* * *}$ & $-35.017^{* * *}$ & 6 \\
\hline RBOB & -1.676 & -1.709 & 4 & $-35.687^{* * *}$ & $-35.675^{* * *}$ & 3 \\
\hline WTI & -1.639 & -1.527 & 2 & $-36.300^{* * *}$ & $-36.311^{* * * *}$ & 2 \\
\hline
\end{tabular}

Notes: Levels are the logarithms of the futures prices. $* * *$ denotes significance at the $1 \%$ level of significance. The lengths of the lags given in the table refer to the Phillips-Perron (PP) test. For the ADF test, all the lags for the loggarithmic levels and first differences are zero. The critical values are: -3.9817 at the $1 \%$ level of significance, 3.4214 at $5 \%$, and -3.1334 at $10 \%$. 
Table 4: Number of Possible Cointegrating Relationships

Full Period: 6/02/2006-1/13/2011

\begin{tabular}{|c|c|c|c|c|c|}
\hline \multirow[t]{2}{*}{$\begin{array}{l}\text { Data Trend: } \\
\text { Test Type }\end{array}$} & $\begin{array}{c}\text { None } \\
\text { No Intercept }\end{array}$ & $\begin{array}{c}\text { None } \\
\text { Intercept }\end{array}$ & $\begin{array}{c}\text { Linear } \\
\text { Intercept }\end{array}$ & $\begin{array}{c}\text { Linear } \\
\text { Intercept }\end{array}$ & $\begin{array}{l}\text { Quadratic } \\
\text { Intercept }\end{array}$ \\
\hline & No Trend & No Trend & No Trend & Trend & Trend \\
\hline Trace & $2 *$ & 1 & 2 & 1 & 1 \\
\hline Max-Eig & $0 *$ & $0 *$ & 0 & 0 & 0 \\
\hline \multicolumn{6}{|c|}{ Start of Recession-Subperiod: 12/03/2007-1/13/2011 } \\
\hline $\begin{array}{l}\text { Data Trend: } \\
\text { Test Type }\end{array}$ & $\begin{array}{c}\text { None } \\
\text { No Intercept } \\
\text { No Trend }\end{array}$ & $\begin{array}{c}\text { None } \\
\text { Intercept } \\
\text { No Trend }\end{array}$ & $\begin{array}{c}\text { Linear } \\
\text { Intercept } \\
\text { No Trend } \\
\end{array}$ & $\begin{array}{c}\text { Linear } \\
\text { Intercept } \\
\text { Trend }\end{array}$ & $\begin{array}{c}\text { Quadratic } \\
\text { Intercept } \\
\text { Trend } \\
\end{array}$ \\
\hline Trace & 2 & $1 *$ & 2 & 1 & 1 \\
\hline Max-Eig & 1 & $1 *$ & 1 & 1 & 1 \\
\hline \multicolumn{6}{|c|}{ Recovery Subperiod: 7/01/2009-1/13/2011 } \\
\hline $\begin{array}{l}\text { Data Trend: } \\
\text { Test Type }\end{array}$ & $\begin{array}{c}\text { None } \\
\text { No Intercept } \\
\text { No Trend } \\
\end{array}$ & $\begin{array}{c}\text { None } \\
\text { Intercept } \\
\text { No Trend } \\
\end{array}$ & $\begin{array}{c}\text { Linear } \\
\text { Intercept } \\
\text { No Trend } \\
\end{array}$ & $\begin{array}{c}\text { Linear } \\
\text { Intercept } \\
\text { Trend } \\
\end{array}$ & $\begin{array}{c}\text { Quadratic } \\
\text { Intercept } \\
\text { Trend } \\
\end{array}$ \\
\hline Trace & 4 & $1 *$ & 1 & 1 & 1 \\
\hline Max-Eig & 1 & $1 *$ & 1 & 1 & 1 \\
\hline \multicolumn{6}{|c|}{ Great Recession Subperiod: 12/03/2007-6/01/2009 } \\
\hline $\begin{array}{l}\text { Data Trend: } \\
\text { Test Type }\end{array}$ & $\begin{array}{c}\text { None } \\
\text { No Intercept } \\
\text { No Trend } \\
\end{array}$ & $\begin{array}{c}\text { None } \\
\text { Intercept } \\
\text { No Trend } \\
\end{array}$ & $\begin{array}{c}\text { Linear } \\
\text { Intercept } \\
\text { No Trend }\end{array}$ & $\begin{array}{c}\text { Linear } \\
\text { Intercept } \\
\text { Trend }\end{array}$ & $\begin{array}{c}\text { Quadratic } \\
\text { Intercept } \\
\text { Trend } \\
\end{array}$ \\
\hline Trace & 3 & $1 *$ & 2 & 1 & 1 \\
\hline Max-Eig & 1 & $1 *$ & 1 & 1 & 1 \\
\hline
\end{tabular}

Notes: The 2007-2009 Great Recession is officially dated to have started in December 2007 and to have ended in June 2009. The economic recovery subperiod starts from July 2009 until January 13, 2011, the end of the sample period. 
Table 5: Cointegrating Equation (full period)

\section{Cointegrating Equation}

Corn(-1)

Ethanol(-1)

Soybean(-1)

Sugar(-1)

$\operatorname{RBOB}(-1)$

Notes: The full period is June 2, 2006 to January 13, 2011. Superscripts a, b and c represent significance at the $1 \%, 5 \%$ and $10 \%$ levels, respectively.

\section{Coefficients}

1.000000

$-0.451863 *$

$-1.193610^{* * *}$

0.066985

$-0.824278^{* *}$ 


\section{Table 6: VEC Model, Block Exogeneity and Weak Exogeneity Tests (full period)}

\begin{tabular}{|c|c|c|c|c|c|c|}
\hline Model & Corn & Ethanol & Soybean & Sugar & $\mathrm{RBOB}$ & WTI \\
\hline ECT & -0.006128 & $-0.01788^{* * * * *}$ & $-0.011933^{* * * *}$ & 0.004999 & -0.010166 & 0.000457 \\
\hline Corn $(-1)$ & 0.023079 & 0.004221 & -0.043164 & -0.057786 & -0.014911 & -0.031189 \\
\hline Corn(-2) & 0.055591 & 0.000721 & 0.037861 & 0.026261 & -0.051536 & 0.004088 \\
\hline Ethanol(-1) & 0.045074 & 0.028632 & -0.033821 & 0.009176 & $-0.077760 *$ & $-0.069342 *$ \\
\hline Ethanol(-2) & -0.033165 & $0.070046^{* *}$ & 0.033561 & 0.059104 & 0.056438 & 0.001912 \\
\hline Soybean(-1) & 0.018993 & -0.006502 & $0.102277 * * *$ & $0.113861 * *$ & 0.071522 & $0.097770^{* * *}$ \\
\hline Soybean(-2) & -0.070674 & -0.025966 & -0.039367 & -0.012373 & 0.001202 & 0.011891 \\
\hline Sugar(-1) & 0.005309 & 0.019822 & 0.001271 & 0.000988 & 0.018791 & -0.002574 \\
\hline Sugar(-2) & -0.021825 & 0.008541 & -0.015256 & -0.025939 & -0.013259 & 0.000298 \\
\hline RBOB(-1) & -0.029580 & -0.042743 & 0.035927 & -0.000894 & 0.081837 & 0.040949 \\
\hline RBOB(-2) & 0.045837 & -0.074496 & 0.001286 & -0.020910 & -0.042565 & 0.000870 \\
\hline WTI $(-1)$ & -0.063907 & -0.002351 & $-0.091963 *$ & -0.090482 & $-0.126104 *$ & -0.091276 \\
\hline WTI(-2) & -0.058098 & 0.033328 & -0.049046 & -0.007501 & 0.060996 & -0.031226 \\
\hline Corn_OI(-1) & -0.003225 & $-0.01067 * * *$ & -0.003992 & $-0.008341^{*}$ & $-0.010111 * *$ & $-0.01096 * * *$ \\
\hline Ethanol_OI(-1) & -0.000233 & -0.000216 & -0.000418 & 0.000482 & -0.000681 & -0.000748 \\
\hline Soy_OI(-1) & $0.009443 *$ & $0.017223 * * *$ & $0.010511 * * *$ & $0.010927 *$ & $0.014642 * * *$ & $0.015386 * * *$ \\
\hline Sugar_OI(-1) & -0.003139 & 0.001692 & -0.000948 & -0.004140 & 0.000814 & -0.003232 \\
\hline LLH & 19010.22 & & & & & \\
\hline AIC & -31.39737 & & & & & \\
\hline $\mathrm{SC}$ & -30.93626 & & & & & \\
\hline & & & & & & \\
\hline & Long-run $\mathrm{Gr}$ & iger Non-caus & ty Test $\alpha(\mathrm{j}, 1)=$ & & & \\
\hline Null: $\alpha=0$ & -0.76 & $-7 * * *$ & -2.8 & -0.2 & -0.88 & 0 \\
\hline Restrictions & $\alpha(1,1)=0$ & $\alpha(2,1)=0$ & $\alpha(3,1)=0$ & $\alpha(4,1)=0$ & $\alpha(5,1)=0$ & $\alpha(6,1)=0$ \\
\hline & Weak Exoge & eity Test, $\beta(1, j$ & & & & \\
\hline Weak Exogeneity & N.A. & -0.98 & $-4.24 * *$ & N.A. & N.A. & N.A. \\
\hline Restrictions & N.A. & $\beta(1,2)=0$ & $\beta(1,3)=0$ & N.A. & N.A. & N.A. \\
\hline & & & & & & \\
\hline & Block Exoge & eity Wald Tes & & & & \\
\hline Block Exogeneity & 14.79845 & 8.561484 & $17.24384 *$ & 11.73092 & 11.82536 & 6.440973 \\
\hline
\end{tabular}

Notes: All variables are expressed in first log differences. $* * *, * *$ and $*$ represent significance at the $1 \%, 5 \%$ and $10 \%$ levels, respectively. Values for the causality tests are Chi-square statistics. The null hypothesis for weak exogeneity is that the estimated coefficients in the cointegrating equation within the VEC models are zero in the long run. The $\beta \mathrm{s}$ contain the loading factors. The null hypothesis for block exogeneity is that an endogenous variable is not jointly caused by the lagged endogenous variables in the VEC equation. 


\section{Table 7: Variance Decomposition (full period)}

VDC for Corn

\begin{tabular}{cccccccc}
\hline \hline Period & S.E. & Corn & Ethanol & Soybean & Sugar & RBOB & WTI \\
\hline \hline 1 & 0.022380 & 100.0000 & 0.000000 & 0.000000 & 0.000000 & 0.000000 & 0.000000 \\
10 & 0.072895 & 99.25368 & 0.004752 & 0.112865 & 0.007884 & 0.577900 & 0.042919 \\
20 & 0.104055 & 98.96809 & 0.002574 & 0.289472 & 0.013396 & 0.701801 & 0.024664 \\
30 & 0.128422 & 98.66489 & 0.003456 & 0.497646 & 0.019065 & 0.798108 & 0.016838 \\
40 & 0.149289 & 98.35672 & 0.006399 & 0.715338 & 0.024608 & 0.880704 & 0.016229 \\
50 & 0.167903 & 98.05731 & 0.010486 & 0.929515 & 0.029849 & 0.952800 & 0.020037 \\
\hline
\end{tabular}

VDC for Ethanol

\begin{tabular}{cccccccc}
\hline \hline Period & S.E. & Corn & Ethanol & Soybean & Sugar & RBOB & WTI \\
\hline \hline 1 & 0.019814 & 21.03586 & 78.96414 & 0.000000 & 0.000000 & 0.000000 & 0.000000 \\
10 & 0.063824 & 23.15080 & 75.27539 & 0.933221 & 0.008213 & 0.547505 & 0.084873 \\
20 & 0.091419 & 24.91101 & 71.02843 & 2.774261 & 0.008341 & 0.962496 & 0.315453 \\
30 & 0.113737 & 26.18146 & 66.82639 & 4.987006 & 0.021280 & 1.372881 & 0.610979 \\
40 & 0.133563 & 27.08762 & 62.94273 & 7.251845 & 0.040816 & 1.755059 & 0.921937 \\
50 & 0.151844 & 27.73313 & 59.48205 & 9.402343 & 0.062849 & 2.097835 & 1.221800 \\
\hline
\end{tabular}

VDC for Soybean

\begin{tabular}{|c|c|c|c|c|c|c|c|}
\hline Period & S.E. & Corn & Ethanol & Soybean & Sugar & RBOB & WTI \\
\hline 1 & 0.018414 & 40.34832 & 2.891866 & 56.75981 & 0.000000 & 0.000000 & 0.000000 \\
\hline 10 & 0.057339 & 41.33826 & 1.349476 & 56.80019 & 0.030938 & 0.395501 & 0.085633 \\
\hline 20 & 0.078670 & 47.32385 & 1.028331 & 50.60967 & 0.085668 & 0.865959 & 0.086520 \\
\hline 30 & 0.094364 & 52.67562 & 0.807861 & 44.70010 & 0.156283 & 1.427753 & 0.232377 \\
\hline 40 & 0.107518 & 57.20533 & 0.646712 & 39.41280 & 0.234242 & 2.024396 & 0.476515 \\
\hline 50 & 0.119262 & 60.94551 & 0.529440 & 34.82134 & 0.313281 & 2.615162 & 0.775266 \\
\hline \multicolumn{8}{|c|}{ VDC for Sugar } \\
\hline Period & S.E. & Corn & Ethanol & Soybean & Sugar & RBOB & WTI \\
\hline 1 & 0.025619 & 8.564538 & 1.118445 & 1.086996 & 89.23002 & 0.000000 & 0.000000 \\
\hline 10 & 0.080263 & 7.572240 & 1.020969 & 1.725952 & 89.21835 & 0.377556 & 0.084937 \\
\hline 20 & 0.113220 & 7.807403 & 0.960241 & 1.456279 & 89.25080 & 0.461107 & 0.064167 \\
\hline 30 & 0.138424 & 8.055048 & 0.909741 & 1.224508 & 89.23337 & 0.529395 & 0.047940 \\
\hline 40 & 0.159633 & 8.281067 & 0.867005 & 1.040344 & 89.18492 & 0.589839 & 0.036824 \\
\hline 50 & 0.178302 & 8.482244 & 0.830541 & 0.894863 & 89.11886 & 0.643936 & 0.029555 \\
\hline
\end{tabular}


VDC for RBOB Gasoline

\begin{tabular}{|c|c|c|c|c|c|c|c|}
\hline Period & S.E. & Corn & Ethanol & Soybean & Sugar & RBOB & WTI \\
\hline 1 & 0.024355 & 11.46524 & 7.719528 & 4.865258 & 1.063297 & 74.88668 & 0.000000 \\
\hline 10 & 0.073829 & 11.89395 & 4.932451 & 5.054221 & 1.295889 & 76.65836 & 0.165127 \\
\hline 20 & 0.102583 & 13.22529 & 4.556290 & 3.861708 & 1.242636 & 77.01334 & 0.100739 \\
\hline 30 & 0.124014 & 14.46506 & 4.300714 & 2.969101 & 1.183658 & 77.00943 & 0.072030 \\
\hline 40 & 0.141786 & 15.58160 & 4.089146 & 2.337470 & 1.128001 & 76.79051 & 0.073272 \\
\hline 50 & 0.157313 & 16.57591 & 3.906100 & 1.903260 & 1.077280 & 76.44253 & 0.094919 \\
\hline \multicolumn{8}{|c|}{ VDC for Crude oil } \\
\hline Period & S.E. & Corn & Ethanol & Soybean & Sugar & RBOB & WTI \\
\hline 1 & 0.023509 & 14.19271 & 7.445498 & 5.716592 & 1.481663 & 51.13063 & 20.03291 \\
\hline 10 & 0.070990 & 13.67899 & 5.331646 & 8.522854 & 1.408151 & 52.46233 & 18.59603 \\
\hline 20 & 0.099936 & 13.86767 & 5.145458 & 8.360837 & 1.387881 & 52.45413 & 18.78403 \\
\hline 30 & 0.122076 & 14.06327 & 5.055191 & 8.116702 & 1.372328 & 52.37958 & 19.01293 \\
\hline 40 & 0.140690 & 14.24087 & 4.993078 & 7.883625 & 1.359239 & 52.29596 & 19.22723 \\
\hline 50 & 0.157056 & 14.39856 & 4.944878 & 7.674416 & 1.347969 & 52.21450 & 19.41968 \\
\hline
\end{tabular}


Table 8: Cointegrating Relationships for Three Subperiods

\begin{tabular}{cccc}
\hline Cointegrating Equation & $\begin{array}{c}\text { Recession start-Sample end } \\
12 / 03 / 2007-1 / 13 / 2011\end{array}$ & $\begin{array}{c}\text { Recovery Period } \\
7 / 1 / 2009-1 / 13 / 2011\end{array}$ & $\begin{array}{c}\text { Recession Period } \\
12 / 03 / 2007- \\
6 / 01 / 2009\end{array}$ \\
\hline Corn(-1) & 1.000000 & 1.000000 & 1.000000 \\
Ethanol(-1) & $-1.055299^{* * *}$ & $-0.844916^{* * *}$ & $-0.849560^{* * *}$ \\
Soybean(-1) & $-0.853327^{* * *}$ & $-2.781268^{* * *}$ & $-0.424451^{* * *}$ \\
Sugar(-1) & 0.047270 & $0.389611^{* * *}$ & 0.058530 \\
RBOB(-1) & -0.030443 & $-2.243525^{* * *}$ & 0.171736 \\
WTI(-1) & 0.163825 & $3.651696^{* * *}$ & $-0.293423^{* * *}$ \\
\hline
\end{tabular}

Notes: The 2007/2009 Great Recession is officially dated to have started from December 2007 and to have ended in June 2009. The economic recovery subperiod in this paper starts from July 2009 until January 13, 2011, the end of the sample peri 


\section{Table 9: VEC Model, Block Exogeneity and Weak Exogeneity Tests for the Recovery Subperiod}

\begin{tabular}{|c|c|c|c|c|c|c|}
\hline Model & Corn & Ethanol & Soy & Sugar & RBOB & WTI \\
\hline ECT1 & -0.010168 & $-0.023235^{* * * *}$ & $-0.028402^{* * * *}$ & $0.022939^{\text {*** }}$ & -0.010417 & -0.002241 \\
\hline $\operatorname{Corn}(-1)$ & -0.025080 & -0.038620 & -0.036716 & -0.048132 & -0.044169 & -0.017690 \\
\hline Ethanol(-1) & 0.138029 & $0.176802^{* * * *}$ & 0.035761 & 0.033313 & 0.018457 & 0.005178 \\
\hline Soy(-1) & -0.004655 & -0.068722 & 0.097349 & 0.074877 & 0.064136 & 0.060709 \\
\hline Sugar(-1) & 0.028854 & $0.044914^{*}$ & 0.011205 & -0.007331 & 0.039098 & 0.010181 \\
\hline RBOB(-1) & 0.108653 & 0.054192 & 0.085143 & 0.101961 & 0.037924 & 0.094827 \\
\hline WTI(-1) & $-0.325381^{* * *}$ & -0.160353 & -0.177040 & $-0.360006^{*}$ & 0.008234 & -0.038421 \\
\hline Corn_OI(-1) & $-0.030455^{*}$ & -0.006844 & 0.014779 & $-0.047819^{* * *}$ & 0.000179 & -0.012911 \\
\hline Ethanol_OI(-1) & 0.002176 & $-0.010475^{* *}$ & $-0.015429^{* * * *}$ & $0.016766^{*}$ & -0.007362 & 0.000806 \\
\hline Soy_OI(-1) & $0.034562^{* *}$ & 0.012077 & -0.008034 & $0.054656^{\text {*** }}$ & 0.003860 & 0.013888 \\
\hline Sugar_OI(-1) & $-0.013756^{* * *}$ & $-0.021393^{* * * *}$ & $-0.026283^{* * * *}$ & 0.008882 & -0.009660 & -0.002901 \\
\hline LLH & 6705.520 & & & & & \\
\hline AIC & -32.99761 & & & & & \\
\hline \multirow[t]{3}{*}{$\mathrm{SC}$} & -32.27189 & & & & & \\
\hline & & & & & & \\
\hline & \multicolumn{6}{|c|}{ Long-run Granger Non-causality Test $\alpha(\mathrm{j}, 1)=0$} \\
\hline Null: $\alpha=0$ & -1.6940 & $-14.7260^{* * * *}$ & $-15.6480^{* * * *}$ & $-3.8180^{* * *}$ & -1.8720 & -0.0920 \\
\hline \multirow[t]{2}{*}{ Restrictions } & $\alpha(1,1)=0$ & $\alpha(2,1)=0$ & $\alpha(3,1)=0$ & $\alpha(4,1)=0$ & $\alpha(5,1)=0$ & $\alpha(6,1)=0$ \\
\hline & \multicolumn{6}{|c|}{ Weak Exogeneity Test, $\beta(1, \mathrm{j})=0$} \\
\hline Weak Exogeneity & N.A. & -2.8900 & $-26.4420^{* * * * *}$ & $-4.1500^{* * *}$ & N.A. & N.A. \\
\hline \multirow[t]{3}{*}{ Restrictions } & N.A. & $\beta(1,2)=0$ & $\beta(1,3)=0$ & $\beta(1,4)=0$ & N.A. & N.A. \\
\hline & & & & & & \\
\hline & \multicolumn{6}{|c|}{ Block Exogeneity Wald Test } \\
\hline Block Exogeneity & $14.79845^{* *}$ & $11.95101 * *$ & 4.203897 & $9.087155^{*}$ & .471844 & 2.086421 \\
\hline
\end{tabular}

Notes: The subperiod is the economic recovery period that spans 7/1/2009 through to the end of the sample. All commodity variables are expressed in first log differences. $* * *, * *$ and $*$ denote significance at the $1 \%, 5 \%$ and $10 \%$ levels, respectively. Values for the causality tests are Chi-square statistics. The null hypothesis for weak exogeneity is that the estimated coefficients in the cointegrating equation within the VEC models are zero in the long-run. The $\beta$ s contain the loading factors. The null hypothesis for block exogeneity is that an endogenous variable is not jointly caused by the lagged endogenous variables in the VEC equation. The lag length is based on both AIC and SBC. 